Article

\title{
Study on the Performance of a Ground Source Heat Pump System Assisted by Solar Thermal Storage
}

\author{
Yu Jin Nam ${ }^{1, *}$, Xin Yang Gao ${ }^{2}$, Sung Hoon Yoon ${ }^{3}$ and Kwang Ho Lee ${ }^{4}$ \\ Received: 20 September 2015; Accepted: 6 November 2015; Published: 25 November 2015 \\ Academic Editor: Timothy Anderson \\ 1 Department of Architectural Engineering, Pusan National University, 2 Busandaehak-ro 63beon-gil, \\ Geumjeong-gu, Busan 609-735, Korea \\ 2 Department of Architectural Engineering, Cheongju University, 298, Daeseong-ro, Cheongwon-gu, \\ Cheongju 360-764, Korea; kuailezhu@naver.com \\ 3 Department of Architecture, Cheongju University, 298, Daeseong-ro, Cheongwon-gu, Cheongju 360-764, \\ Korea; shyoon@cju.ac.kr \\ 4 Department of Architectural Engineering, Hanbat National University, San 16-1, Dukmyung-Dong, \\ Yuseong-Gu, Daejeon 305-719, Korea; kwhlee@hanbat.ac.kr \\ * Correspondence: namyujin@pusan.ac.kr; Tel.: +82-51-510-7652; Fax: +82-51-514-2230
}

\begin{abstract}
A ground source heat pump system (GSHPS) utilizes a relatively stable underground temperature to achieve energy-saving for heating and cooling in buildings. However, continuous long-term operation will reduce the soil temperature in winter, resulting in a decline in system performance. In this research, in order to improve the system performance of a GSHPS, a ground heat pump system integrated with solar thermal storage was developed. This solar-assisted ground heat pump system (SAGHPS) can both maintain the balance of the soil temperature effectively and achieve higher system performance than the conventional system. In this paper, in order to examine the characteristics of the system, a dynamic simulation was conducted under various conditions. The results of our case study provide specific operation data such as heat exchange rate, heat source temperature, and heat pump COP. As a result, the heat pump COP of SAGHPS was 4.7\%, 9.3\% higher than that of the GSHPS.
\end{abstract}

Keywords: solar thermal storage; ground source heat pump system; simulation; case study; LCC

\section{Introduction}

Recently, renewable energy application technology is becoming an interesting issue in the building sector [1]. In particular, systems using natural heat sources such as solar and ground heat are receiving great attention due to their huge potential. A ground source heat pump system (GSHPS) provides an obvious way to meet the requirements of space heating applications. Compared with conventional air source heat pump systems, it represents a more stable and effective was to use the renewable energy stored under the ground as a heat source. According to the ASHRAE definition, ground heat pump systems are divided into three types: surface water heat pump systems (SWHPSs), ground water source heat pump systems (GWHPSs), and ground-coupled heat pump systems (GCHPSs). Unlike the other two systems, a GCHPS achieves heat transfer with a closed-loop ground heat exchanger (GHE), and it pollutes less and is more stable. In this regard, it has received more attention. In Europe, especially in Switzerland, Austria, and Germany, the utilization of GCHPSs is growing rapidly. More than 30,000 units have been installed in Switzerland [2] and over 140,000 GCHPS have been installed in the USA [3].

Generally, a GCHPS uses one or multiple boreholes as the ground heat exchanger to extract heat from the soil. However, under long-term operation conditions or when heating a dominant 
building, the underground soil temperature will gradually decrease and the system performance would also suffer. In order to maintain stable system performance, it is necessary to increase the number of boreholes or install additional heat source systems, but, the additional cost and the system performance would then be important issues because the installation of boreholes is fairly expensive. Several researchers have suggested GCHPSs combined with solar collectors because of the excellent resulting performance. In an early experiment, Bose [4] verified that the solar-assisted heat pump system (SAHPS) with geothermal energy storage could improve the energy efficiency. Ozgener et al. [5] suggested a solar-assisted ground-source heat pump greenhouse heating system and conducted an experiment with a $50 \mathrm{~m}$ vertical U-shaped geothermal heat exchanger. The exergetic efficiency of the overall system was found to be $67.7 \%$ and the experimental results also showed that, if the ambient temperature is very low, the monovalent central heating operation cannot meet the heating load of the greenhouse. Bakirci et al. [6] also installed an experimental system for investigating the thermal performance of a solar-ground source heat pump system in heating mode.

The combination with solar heat and ground heat is very simple idea, but the prediction of system performance and the system optimization are still complicated issues because they must consider various conditions such as local climate, system composition and capacity, operation time, and so on. In order to predict the system performance and develop a design method, several simulation or analytic approach studies have been carried out. Trillat-Berdal $[7,8]$ described a ground-coupled heat pump combined with thermal solar collectors. By using the transient system (TRNSYS) software, they also simulated the heat transfer between the ground heat exchanger and the ground. Yang et al. [9] simulated the performance of a solar-source heat pump system operated in an alternate or combined mode; the results indicated that a resuming-rate of $30 \%-60 \%$ of the earth temperature near the buried coil is preferable when a solar-earth source heat pump system (SESHPS) is operated alternately for a period of $24 \mathrm{~h}$. Nam [10] and Han et al. [11] conducted research simulations on a heat pump system that utilizes solar heat and ground heat as the heat sources for cooling and heating. The results showed the developed system had a comparative advantage in a cold climate compared with an air source heat pump system. Lazzarin studied the operation method for dual source heat pump system with solar and ground heat through various case studies [12]. His studies provided quantitative operation data for the system [13] and demonstrated the performance advantages of the system through a case study of a new school building [14] and energetic assessment [15]. However, there are few researches simultaneously considering the building load conditions and local climate conditions, and the system capacity. In particular, studies on the possibility of underground heat storage of solar heat is rare.

Recently, through the International Energy Agency (IEA) Annex 44 and Annex 38, solar and ground heat pump systems were discussed and a design method and its system efficiency were suggested [16]. They showed more than 80 combinations of solar and heat pump systems, and suggested a performance assessment method. However, the consideration of underground thermal storage using solar heat was not sufficient. Most solar systems need a heat storage tank due to address the mismatch between the time of heat collection and heat supply, but it has the additional problem of space and cost. In this study, in order to recover the soil temperature in GSHPS and improve the system performance, underground heat storage using solar heat was considered without the heat storage tank. In this paper, the system performance was analyzed by dynamic simulation code (TRNSYS 17) and a case study under various conditions such as operation schedule, system capacity, and local climate was conducted for the optimum system design. Furthermore, we compared the performance cost between the suggested ground heat pump system and a general ground heat pump system under the same conditions. 


\section{System Summary and Operation Strategy}

\subsection{System Summary}

Figure 1 shows a conceptual diagram of the solar-assisted ground heat pump system (SAGHPS). As shown in Figure 1, the SAGHPS consisted of a solar collector, a heat pump, borehole heat exchangers, circulation pumps (P1, P2, P3), and three-way valves (V1, V2). A thermal storage tank could be good choice in the solar heat collection system, but in this case, additional space and cost would be necessary. Furthermore, precise heat insulation of piping and tanks against heat loss should also be considered in cold climates. The size and the operation characteristics depend on the capacity of the heating load and the equipment. In this case, a small tank below $300 \mathrm{~L}$ can be used but, this also require similar installation cost and space, so this study tried to find a thermal storage method without the tank and finally settled on using underground heat storage. All these devices are connected by water-loop piping. The SAGHPS has three loops, all of which can be controlled by three-way valves and the ON/OFF of circulation pumps.

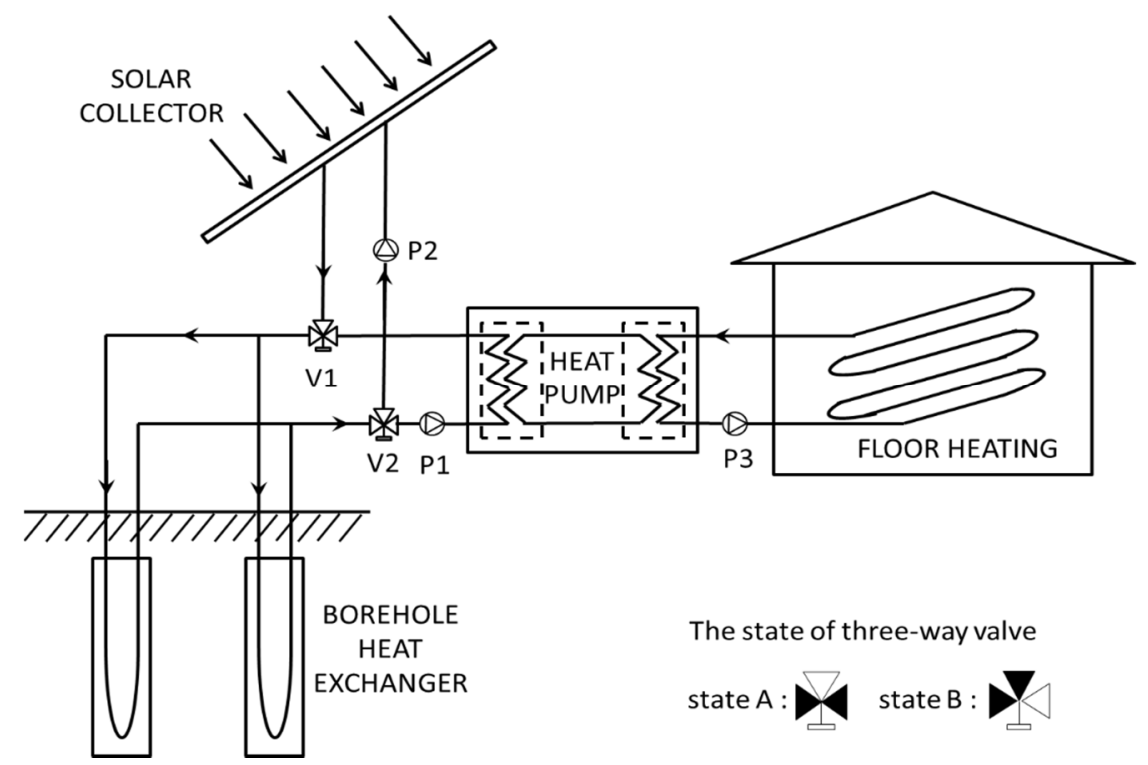

Figure 1. Conceptual diagram of the solar-assisted ground heat pump system (SAGHPS).

\subsection{Operation Strategy}

In this study, the simulation model was assumed as heating a small-scale housing unit. The heating schedule was set considering an ordinary family of four persons in Korea [17]. It was assumed that during the daytime, all of family go out and work or study, and in nighttime, they rest and sleep in the house. Considering the schedule of a general four-person household, the system should run in different modes at different time intervals. Two operation modes are suggested in this SAGHPS, categorized according to the controls on the valves and circulation pumps. They can be summarized as follows:

\subsubsection{Heating Mode (8 P.M. $<t<5$ A.M.)}

In heating mode, $\mathrm{P} 1$ and $\mathrm{P} 3$ are in motion, while $\mathrm{V} 1$ and $\mathrm{V} 2$ are controlled in state $\mathrm{A}$. The system starts with a geothermal heat source for heating the room. Within the predetermined time interval $(20<t<5)$, the system start and stop are dependent on the temperature of the room $\left(T_{\mathrm{r}}\right)$. If $T_{\mathrm{r}}>22^{\circ} \mathrm{C}$, the system will stop temporarily, and when $T_{\mathrm{r}}<22{ }^{\circ} \mathrm{C}$, the system will start again. The whole system will be shut down completely after five o'clock. 


\subsubsection{Solar Thermal Storage Mode (6 A.M. $<t<6$ P.M.)}

The solar thermal storage mode starts at 6 a.m., in this mode, the solar collection system combined with the borehole heat exchanger works for thermal storage while only P2 is turned on, and V1 and V2 are kept in state B. In this process, if the outlet temperature of the solar collector $\left(T \mathrm{~s}_{\text {out }}\right)$ is higher than the average temperature of the soil $\left(T_{\text {soil }}\right)$, the thermal heat absorbed by solar collector will be transferred to the ground through the borehole heat exchanger. Finally, this process will end at 6 P.M. The running processes of the whole system can be confirmed in Figure 2.

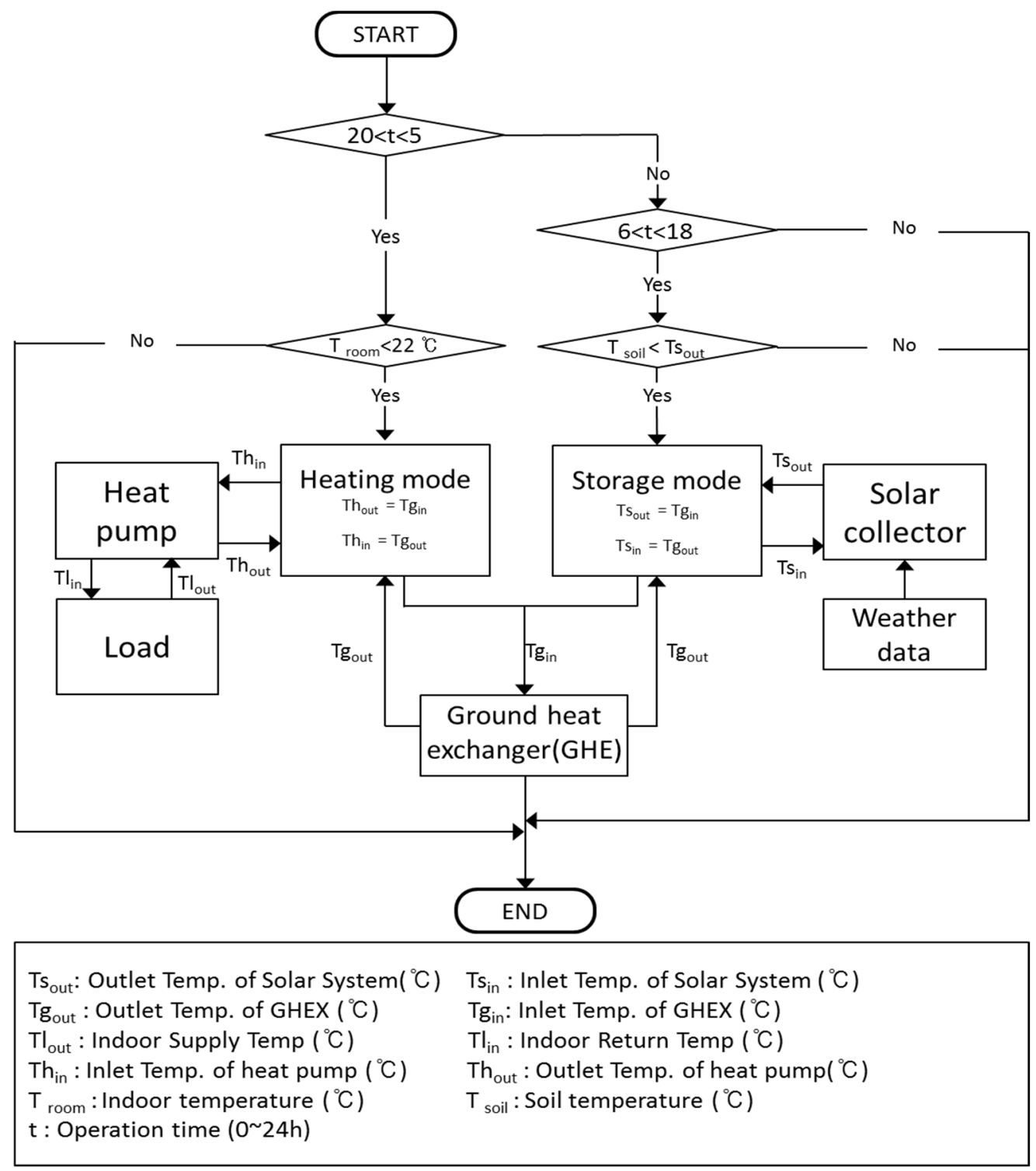

Figure 2. Flow chart of the running processes.

\section{Simulation Introduction}

\subsection{System Summary}

In this paper, in order to simulate and analyze the solar-assisted ground heat pump system (SAGHPS), a performance prediction model of system was created using TRNSYS. TRNSYS is a dynamic simulation program with a modular structure. It utilizes system components which are made by differential equations for the calculation of system performance. The numerical models for 
the subsystem components are given in terms of their ordinary differential or algebraic equations [18]. The simulation model is shown in Figure 3.

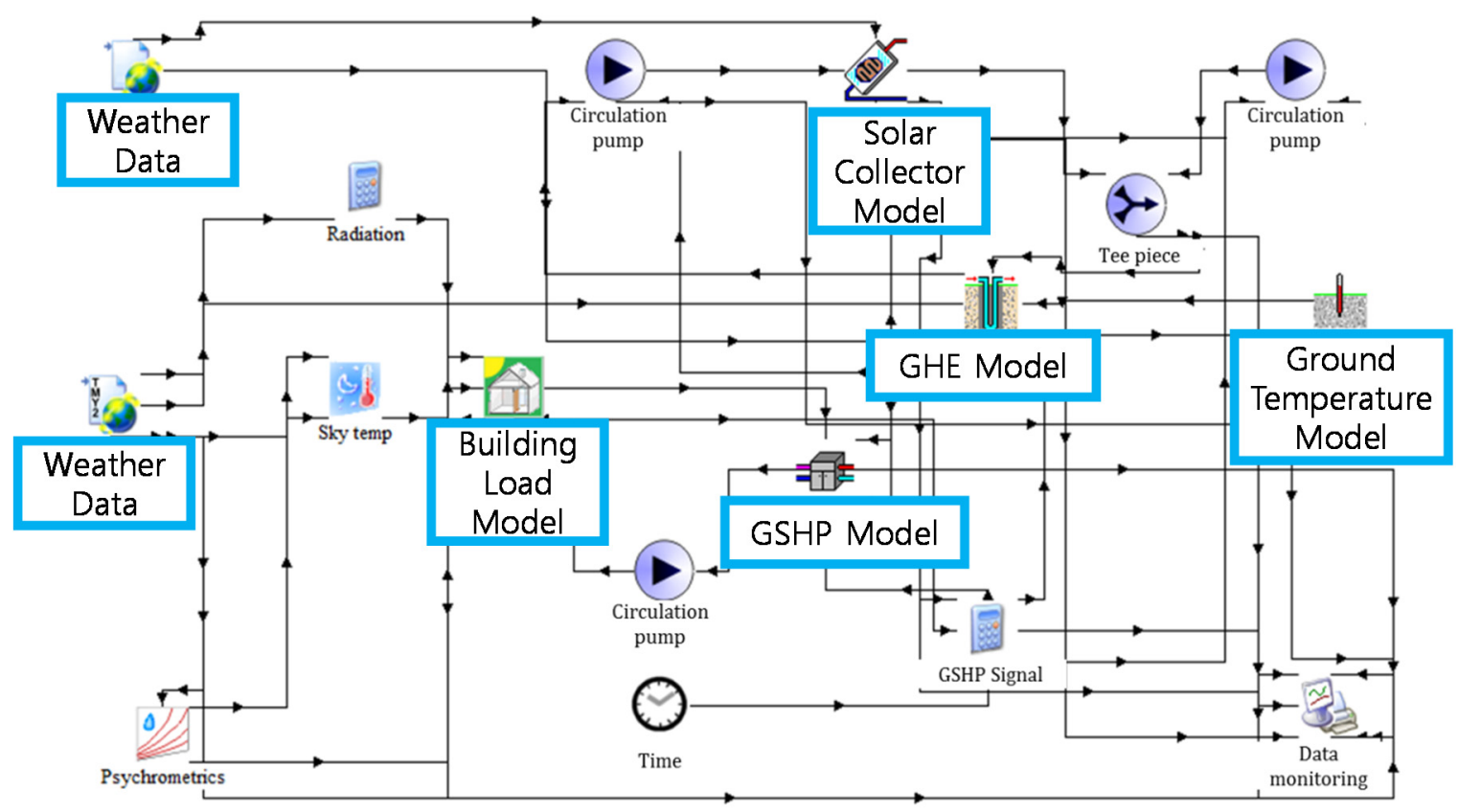

Figure 3. Performance prediction model.

The building was simplified into a single zone and the structural condition of the building was modeled using TRNBuild. In addition, a serpentine tube solar collector model was used for the solar collection systems. As shown in Figure 5, a vertical U-tube ground heat exchanger model (DST model) was used for heat extraction and storage. This model was developed at the Lund Institute of Technology in Sweden [19] and incorporated into TRNSYS by Pahud and Hellström [20]. The storage volume can be calculated as follows:

$$
V_{\mathrm{DST}}=\pi \times \mathrm{n} \times h \times(0.525 \times \mathrm{B})^{2}
$$

For each time step, the fluid temperature can be given by:

$$
T_{\text {fluid,out }}=\beta \times T_{\text {fluid, in }}+(1-\beta) \times\left(T_{\mathbf{b}}\right)
$$

The heat transfer rate can be expressed as:

$$
Q_{\text {heat }}=\mathrm{c} \times \mathrm{m} \times\left(T_{\text {fluid, in }}-T_{\text {fluid, out }}\right)
$$

Simultaneously, the GSHP unit was modeled using the water-to-water heat pump model, whereby the capacity of the model was adjusted by modifying the data file to meet the heating load. When the heat pump is determined as being ON in the heating mode, the heat pump model calls the TRNSYS data subroutine with the input source and load fluid. The COP of the heat pump in the heating mode can be given by Equation (4):

$$
\mathrm{COP}_{\mathrm{HP}}=\frac{\text { Cap }}{P_{\mathrm{HP}}}
$$

Figure 4 shows the performance curve for the heat pump used in this research, showing the relationship between the heat source temperature and the COP of the heat pump. 
The amount of energy absorbed from the fluid stream can be defined as:

$$
Q_{\text {absorbed }}=\text { Cap }-P_{\mathrm{HP}}
$$

The outlet temperatures of the two liquid streams can be calculated as follows:

$$
\begin{gathered}
T_{\text {source, out }}=T_{\text {source, in }}-\frac{Q_{\text {absorbed }}}{\mathrm{mc}} \\
T_{\text {load, out }}=T_{\text {load, in }}+\frac{\text { Cap }}{\mathrm{mc}}
\end{gathered}
$$

In order to ensure that the systems work under different strategies, several temperatures were used as control signals for the heat pump and circulation pumps.

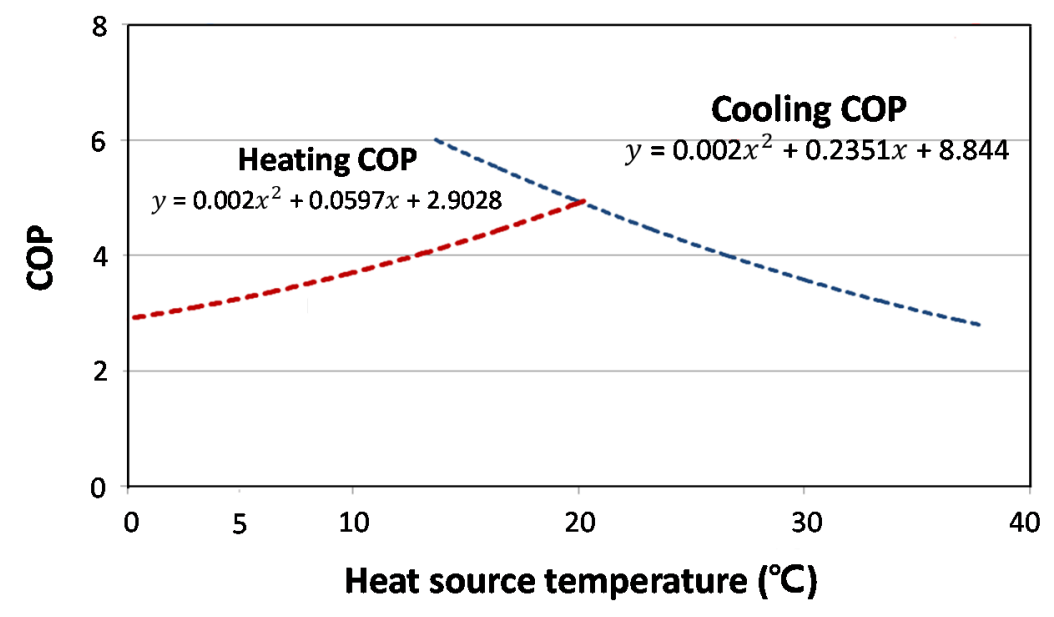

Figure 4. Performance curve of heat pump. Reproduced with permission of [21]. Copyright Elsevier, 2008.

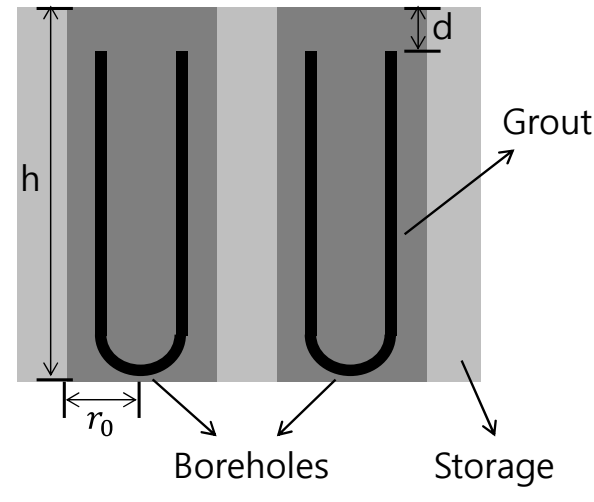

Section View

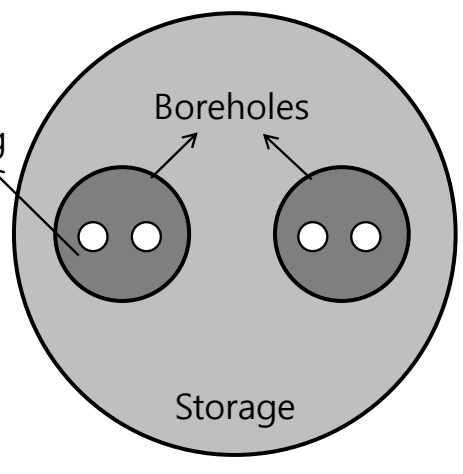

Top View

Figure 5. Conceptual diagram of the DST model. Reproduced with permission of [20]. Copyright TRNSYS, 2015.

\subsection{Simulation Conditions}

In this paper, it was assumed that the system was identified as heating equipment for a $100 \mathrm{~m}^{2}$ single-family house in Seoul. According to the load calculation program established by TRNSYS, the peak heating load can be calculated as $85.13 \mathrm{~W} / \mathrm{m}^{2}$. Therefore, in order to match the heat required for the whole room and considering the stability of the system, a 3RT heat pump model was used in 
this simulation study. Moreover, for heat source equipment, the depth of the borehole heat exchanger should also match the heat pump's capacity. The relationship of the heat pump's capacity and depth of borehole heat exchanger is shown as:

$$
h=\frac{\text { Cap }}{q}
$$

Based on the previous study [22], the heat exchange rate of the GHE used in this study is about $40 \mathrm{~W} / \mathrm{m}$. Therefore, with Equation (8), $300 \mathrm{~m}$ could be suggested as the depth of GHE. The important simulation parameters of the system are shown in Table 1.

Table 1. Basic simulation parameters.

\begin{tabular}{|c|c|c|}
\hline Items & Unit & Value \\
\hline \multicolumn{3}{|l|}{ Building } \\
\hline Design temperature & ${ }^{\circ} \mathrm{C}$ & 22 \\
\hline Scale & $\mathrm{m}$ & $10 \times 10 \times 3$ \\
\hline U-value of external wall, roof, floor & $\mathrm{W} /\left(\mathrm{m}^{2} \mathrm{~K}\right)$ & $0.418,0.193,0.583$ \\
\hline Solar collectors & $\circ$ & \\
\hline Area & $\mathrm{m}^{2}$ & 50 \\
\hline Titled angle & & 45 \\
\hline Flow rate & $\mathrm{kg} / \mathrm{h}$ & 3600 \\
\hline \multicolumn{3}{|l|}{ Ground heat exchangers } \\
\hline Inner diameter & $\mathrm{mm}$ & 29 \\
\hline Outer diameter & $\mathrm{mm}$ & 35 \\
\hline Center -to-center half distance & $\mathrm{mm}$ & 50 \\
\hline Pipe thermal conductivity & $\mathrm{W} /(\mathrm{m} \cdot \mathrm{K})$ & 0.41 \\
\hline Flow rate(Heating mode) & $\mathrm{kg} / \mathrm{h}$ & 2500 \\
\hline Flow rate(Heat storage mode) & $\mathrm{kg} / \mathrm{h}$ & 2000 \\
\hline \multicolumn{3}{|l|}{ Boreholes } \\
\hline Fill thermal conductivity & $\mathrm{W} /(\mathrm{m} \cdot \mathrm{K})$ & 1.5 \\
\hline Number & - & 3 \\
\hline Depth & $\mathrm{m}$ & 100 \\
\hline Diameter & $\mathrm{mm}$ & 200 \\
\hline \multicolumn{3}{|l|}{ Ground } \\
\hline Soil thermal conductivity & $\mathrm{W} /(\mathrm{m} \cdot \mathrm{K})$ & 3.5 \\
\hline Soil density & $\mathrm{kg} / \mathrm{m}^{3}$ & 3000 \\
\hline Heat capacity & $\mathrm{kJ} /\left(\mathrm{m}^{3} \mathrm{~K}\right)$ & 2920 \\
\hline \multicolumn{3}{|l|}{ System operation time } \\
\hline Heating mode & $\mathrm{h}$ & 20:00 5:00 \\
\hline Storage mode & $\mathrm{h}$ & $6: 00 \sim 18: 00$ \\
\hline
\end{tabular}

\section{Results and Discussion}

\subsection{Comparison with a General Ground Source Heat Pump System}

Based on the aforementioned operation conditions and component models of the systems, the heating process of the system was simulated from November 1st to the end of March. As shown in Figure 6, the soil temperature is affected by different operation modes and solar radiation fluctuations. From 22 January to 24 January, with the high solar radiation, the injection energy to the ground is $419.8 \mathrm{~kW} \cdot \mathrm{h}$ and the extraction energy from the ground is $270.3 \mathrm{~kW} \cdot \mathrm{h}$. Therefore, as seen in Figure 6, the temperature of the soil increased over these three days. In contrast, from 25 January to 27 January, the solar radiation was not as strong as it was over these three days, and the injection energy to the ground was only $104.1 \mathrm{~kW} \cdot \mathrm{h}$, which is $137.1 \mathrm{~kW} \cdot \mathrm{h}$ less than the extraction energy. Therefore, the temperature of the soil decreased again. 
From November to March, the total injection energy was $8110.0 \mathrm{~kW} \cdot \mathrm{h}$. Although this is less than the total extraction energy $(10,062.9 \mathrm{~kW} \cdot \mathrm{h})$, it is also effective for the recovery of the soil temperature. As shown in Figure 7, within the same condition, after 5 months of operation, the soil temperature of SAGHPS decreased from $16^{\circ} \mathrm{C}$ to $15.9{ }^{\circ} \mathrm{C}$. In addition, the soil temperature of GSHPS reduced to $10.7^{\circ} \mathrm{C}$. Because of the relatively high ground temperature, the heat source water temperature of SAGHPS was also higher than that of GSHPS. This is confirmed in Figure 8.

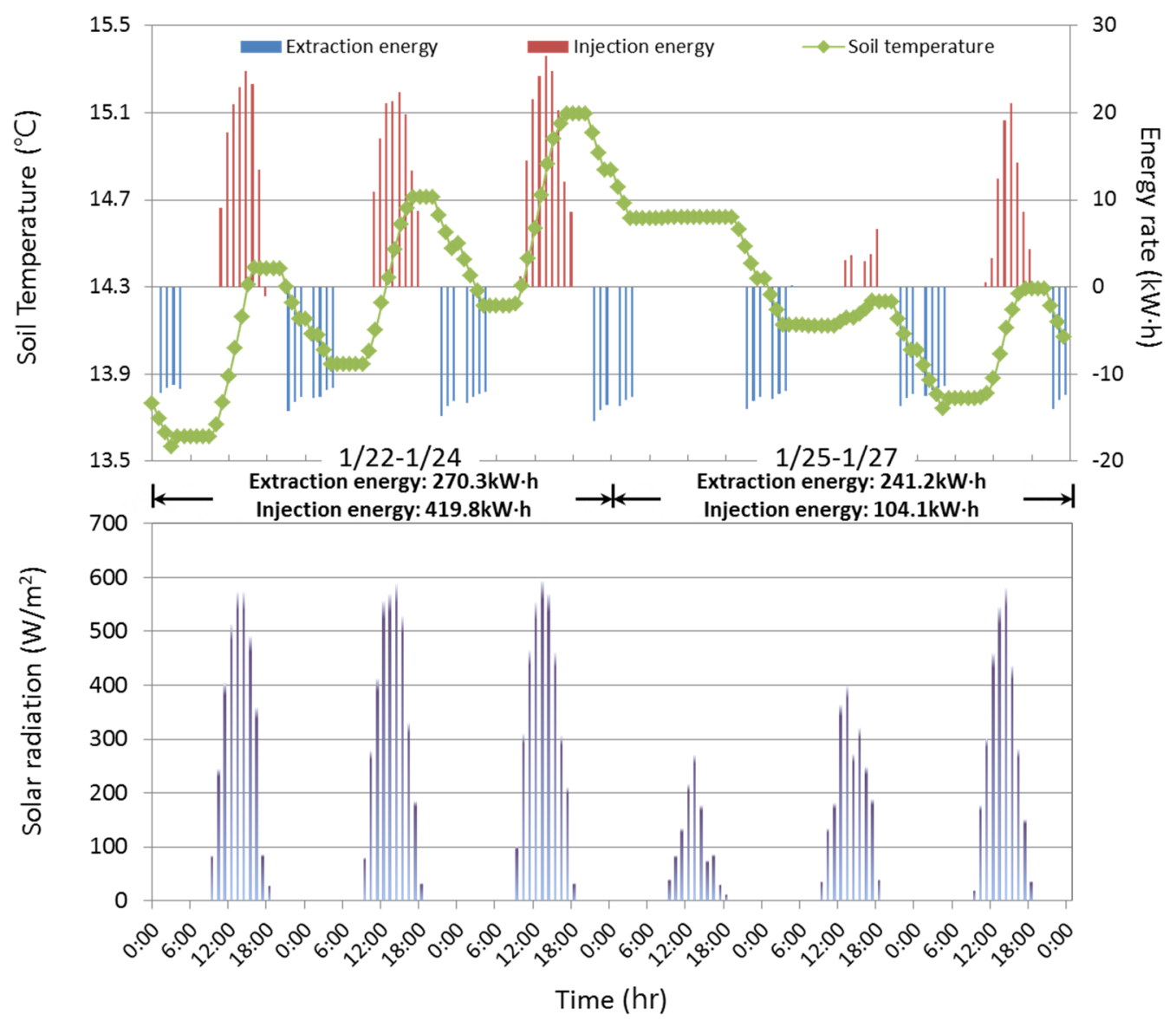

Figure 6. Simulation result of SAGHPS.

The main simulation results are shown in Table 2. As seen in Table 2, because of the long term operation (5 months), the heat exchange rate of GSHPS drops from $41.1 \mathrm{~W} / \mathrm{m}$ to $30.8 \mathrm{~W} / \mathrm{m}$. Therefore, the heat source temperature and heat pump COP drop to $6.6{ }^{\circ} \mathrm{C}$ and 4.0 , respectively. On the other hand, from November to February, although the performance values of SAGHPS as well as GSHPS drop, this is better than that of GHPS. We can also see that compared with February, in March the performance values actually increased. This is because, as shown in Figure 9, the monthly average of solar radiation in March was higher than that in the other months. Therefore, the injection energy into the ground is greater than the extraction energy from the ground. In addition, depending on the operation period of the solar system, the difference of total system performance also increases. As shown in Figure 10, in November, the difference in the heat exchange rate between the two systems was $25.1 \%$ and in March, the heat exchange rate of SAGHPS was $47.0 \mathrm{~W} / \mathrm{m}$, which is $52.6 \%$ higher than that of GSHPS. The heat pump COP of SAGHPS was $4.7 \%$ and $22.5 \%$ higher than that of GSHPS. 


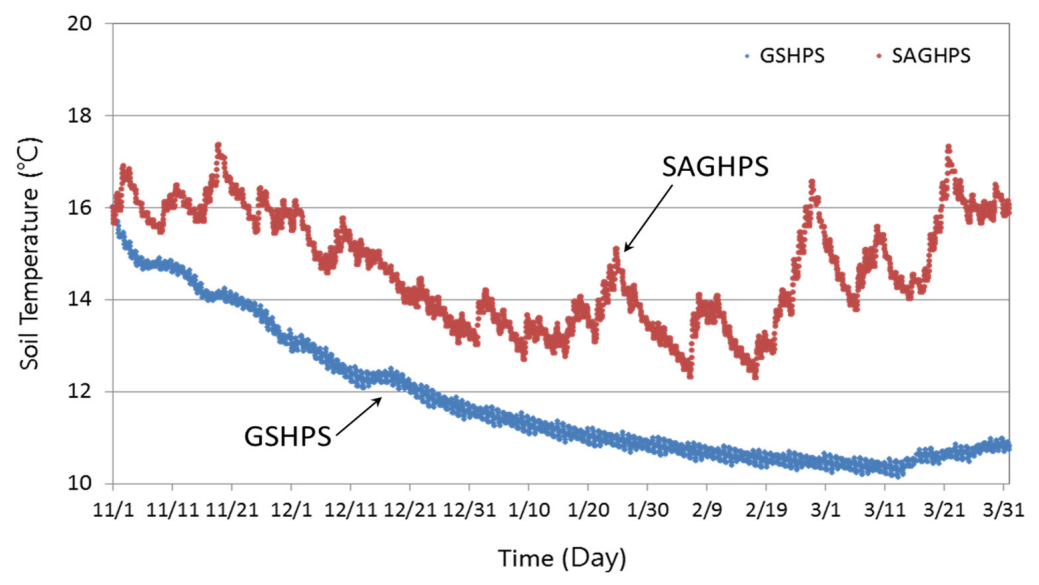

Figure 7. The diversification of soil temperature with different systems.

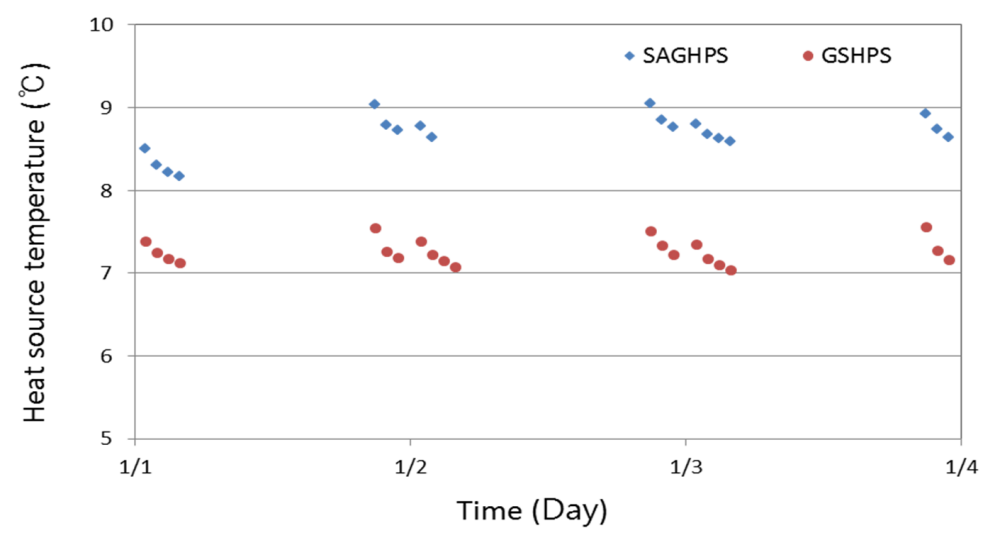

Figure 8. The heat source temperature in different systems.

Table 2. Simulation results.

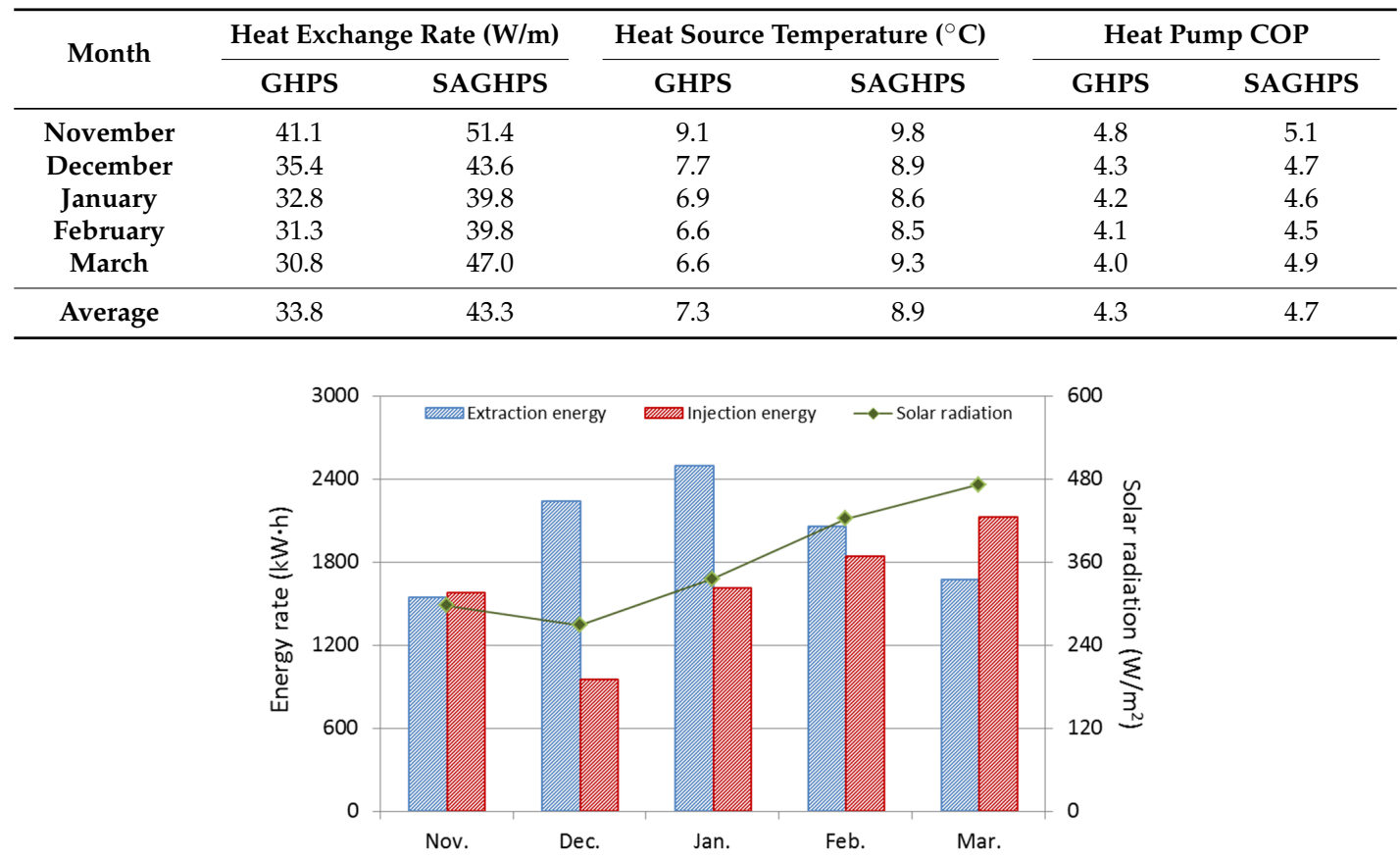

Figure 9. Simulation result of energy rate and solar radiation. 


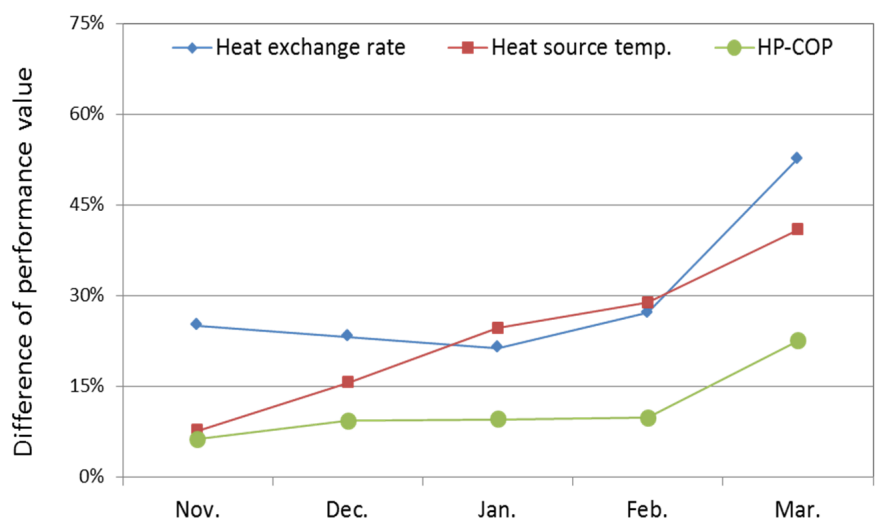

Figure 10. Difference of performance value between the two systems.

\subsection{Performance Analysis with Different Solar Collector Areas}

In this section, the performance of SAGHPS is analyzed with a different solar collector area. The simulation results are shown in Table 3. With the increase of the collector area, more solar energy is absorbed. Therefore, as seen in Table 3, when the collector area is $90 \mathrm{~m}^{2}$, the injection energy to the ground is $12,164.9 \mathrm{~kW} \cdot \mathrm{h}$, which is $78.1 \%$ higher than that when the collector area is $50 \mathrm{~m}^{2}$. In addition, because of the high soil temperature, all performance values increased. However, Figure 11 shows that with the increase of the collector area, the solar storage ratio reduces. This means that, with the increase of the collector area, more absorbed solar energy flows away during the whole operation. The solar storage ratio can be calculated as follows:

$$
\eta=\frac{Q_{\text {injection }}}{Q_{\text {solar }}}
$$

Table 3. Simulation results with different collector area.

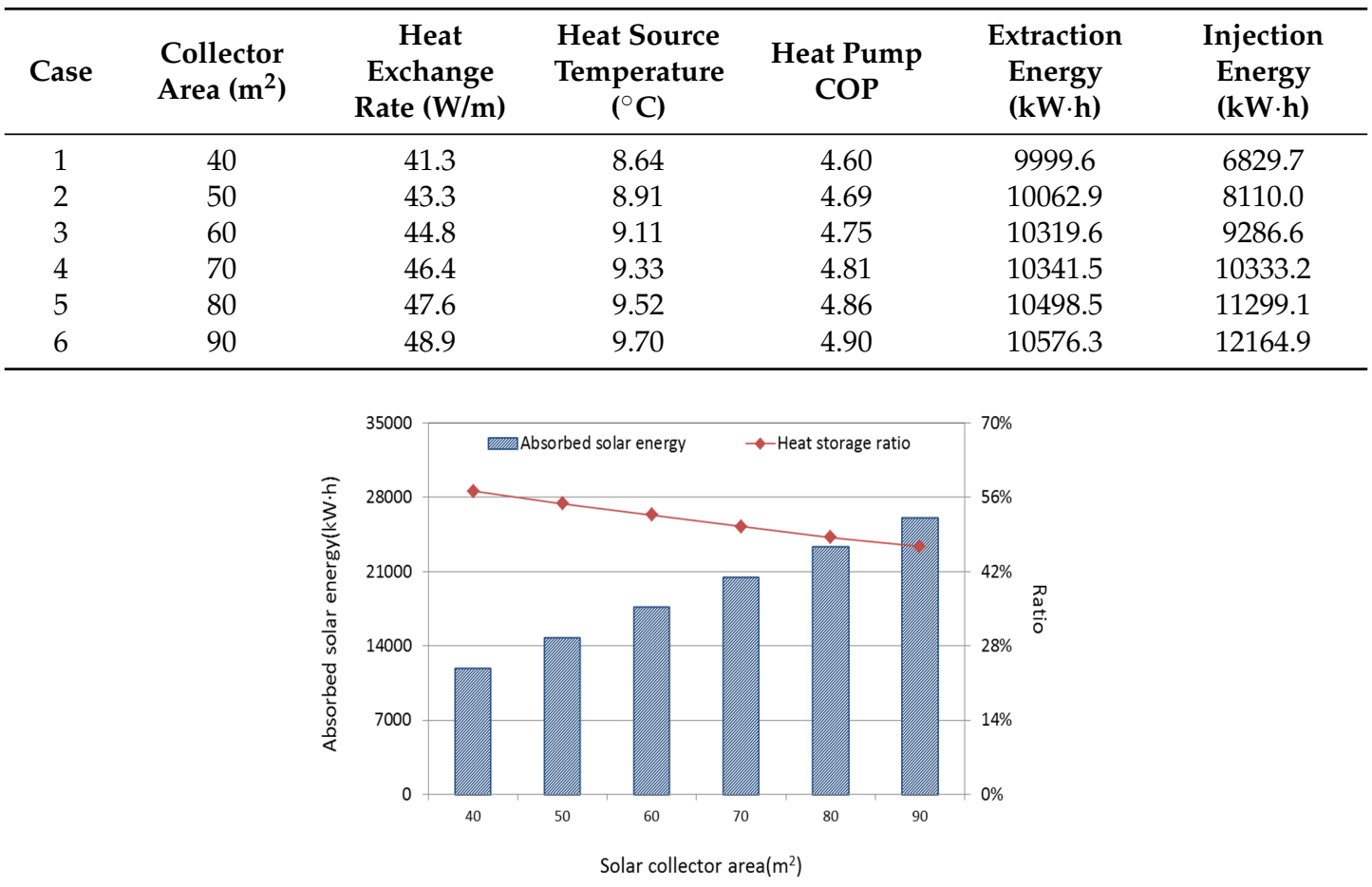

Figure 11. Simulation result of absorbed solar energy and storage ratio. 
In the case of increasing the collector area, although the heating performance of the system increased, higher investment costs will be incurred for the increased collector. In order to analyze the feasibility of the suggested system, the life cycle cost (LCC) assessment between the Air Source Heat Pump System (ASHPS), GSHPS, and SAGHPS was conducted. The investment costs and operation costs were calculated based on the reference price provided by Korea Energy Management Corporation (KEMCO) and Korea Electric Power Corporation (KEPCO). In addition, in order to analyze the power consumption of ASHPS, the seasonal performance factor of ASHPS was assumed as 1.5 [23]. The investment costs and operation costs are shown in Table 4. The life cycle cost can be calculated as follows:

$$
\begin{gathered}
P_{\mathrm{F}}=\frac{F}{(1+i)^{n}} \\
P_{\mathrm{A}}=\frac{A[(1+i)-1]}{i(1+i)^{n}} \\
P=P_{\mathrm{F}}+P_{\mathrm{A}}
\end{gathered}
$$

$P_{\mathrm{F}}$ is a non-recurring cost and $P_{\mathrm{A}}$ is a recurring cost. $i$ is the rate of discount, based on The Bank of Korea, which is estimated to be $3.13 \%$. The LCC assessment results are shown in Figure 12. Compared with ASHPS, the payback period of the additional investment costs in GSHPS is about 7 years. In Case 2, the payback period of the additional investment costs in SAGHPS is about 10 years; in Case4, about 11 years; and in Case 6, about 12 years.

Table 4. The calculation results of investment costs and operation costs.

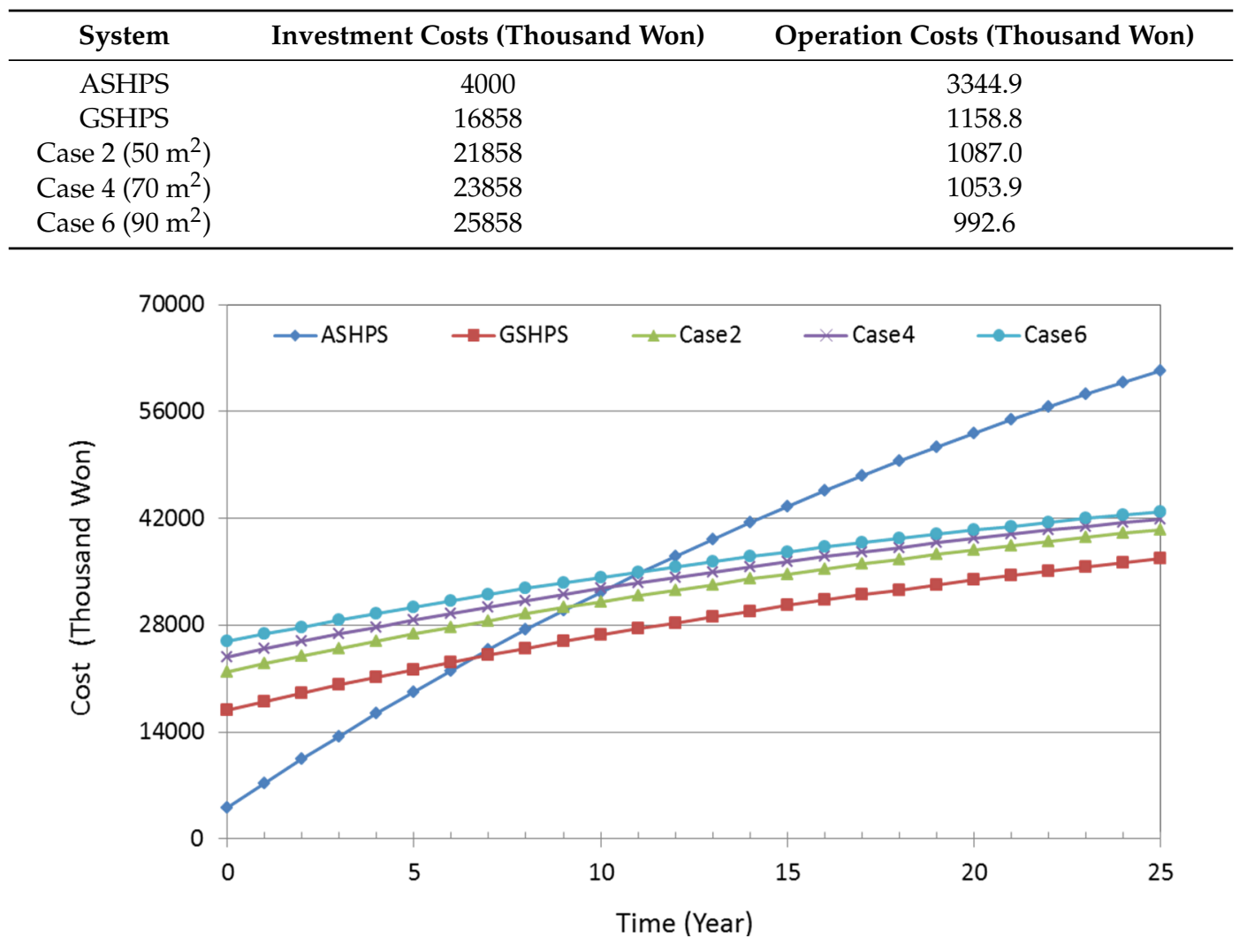

Figure 12. Results of life cycle cost (LCC) assessment. 


\subsection{Performance Analysis with Different Conductivity of Grouting}

The effectiveness of heat transfer with the ground is a critical factor in designing a ground heat pump system. However, the thermal conductivity of the surrounding soil, borehole diameter, and grout volume are not the only factors to be considered. The conductivity of grouting also affects performance. In this section, the performance was analyzed with different thermal conductivities of grouting. The simulation results are shown in Table 4 . When the thermal conductivity of grouting is $2.1 \mathrm{~W} /(\mathrm{m} \cdot \mathrm{K})$, the system achieves the best performance. As seen in Table 5, the heat exchanger rate is $47.1 \mathrm{~W} / \mathrm{m}$, the average heat source temperature is $9.45^{\circ} \mathrm{C}$, and the heat pump COP is 4.84 , which are $10.5 \%$ higher than when the thermal conductivity of grouting is $0.9 \mathrm{~W} /(\mathrm{m} \cdot \mathrm{K})$. Simultaneously, in Figure 13, with the increase of thermal conductivity, the solar storage ratio increases from $52.3 \%$ to $56.0 \%$. Therefore, compared with the other means, the way in which high thermal conductivity grouting is used can increase the performance of both the heating pattern and the solar heat storage pattern.

Table 5. Simulation results with different conductivity of grouting.

\begin{tabular}{ccccccc}
\hline Case & $\begin{array}{c}\text { Thermal } \\
\text { Conductivity } \\
(\mathbf{W} /(\mathbf{m} \cdot \mathbf{K}) \mathbf{)}\end{array}$ & $\begin{array}{c}\text { Heat } \\
\text { Exchange } \\
\text { Rate }(\mathbf{W} / \mathbf{m})\end{array}$ & $\begin{array}{c}\text { Heat Source } \\
\text { Temperature } \\
\mathbf{(} \mathbf{C})\end{array}$ & $\begin{array}{c}\text { Heat Pump } \\
\mathbf{C O P}\end{array}$ & $\begin{array}{c}\text { Extraction } \\
\text { Energy } \\
\mathbf{( k W} \cdot \mathbf{h})\end{array}$ & $\begin{array}{c}\text { Injection } \\
\text { Energy } \\
\mathbf{( k W} \cdot \mathbf{h})\end{array}$ \\
\hline 1 & 0.9 & 36.4 & 7.84 & 4.38 & 9511.4 & 7727.8 \\
2 & 1.2 & 40.2 & 8.48 & 4.55 & 9941.7 & 7970.6 \\
3 & 1.5 & 43.3 & 8.91 & 4.69 & $10,062.9$ & 8110.0 \\
4 & 1.8 & 45.5 & 9.22 & 4.77 & $10,265.6$ & 8212.7 \\
5 & 2.1 & 47.1 & 9.45 & 4.84 & $10,490.8$ & 8291.5 \\
\hline
\end{tabular}

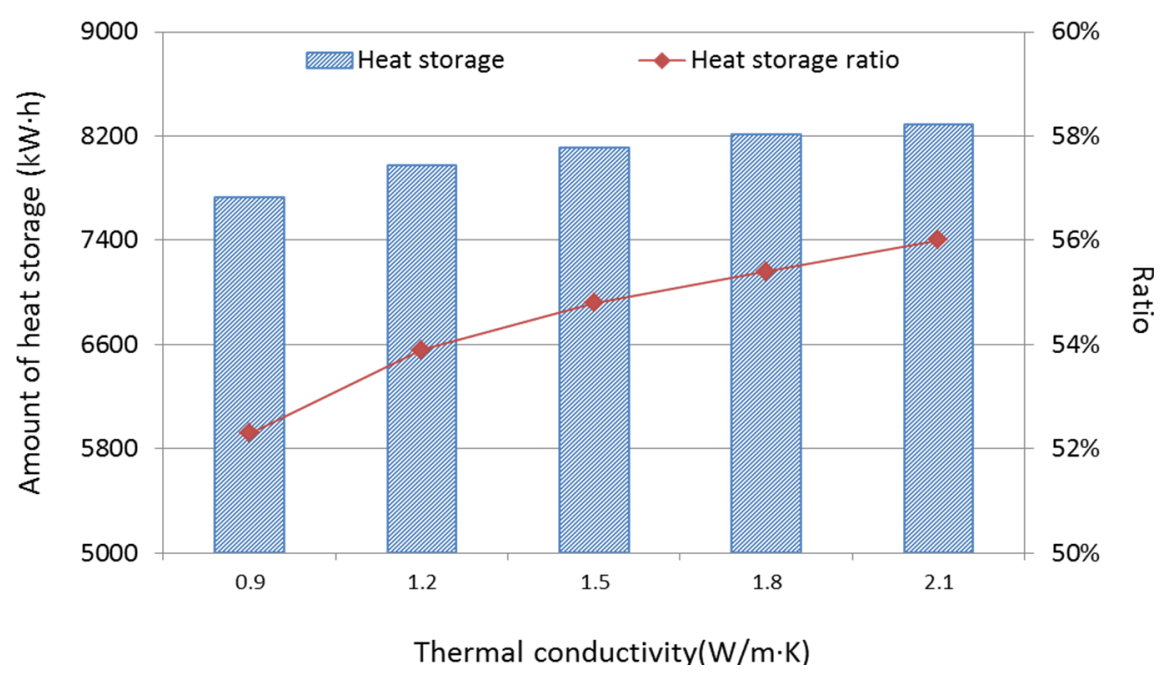

Figure 13. Simulation result of injection solar energy and storage ratio.

\subsection{Performance Analysis with Different Weather Conditions}

Generally, the performance of SAGSHP systems depends on the local climate conditions [20]. The performance of underground heat storage also could be variable depending on them. In this study, three locations were compared in order to find the differences in system performance according to local climate factors such as ambient temperature, solar radiation, energy demand, etc. On the premise that the ground conditions in the three locations are considered to be the same, the performance of SAGHPS was analyzed with different weather conditions. Figure 14 shows the location information of the three cities, which are selected for analysis at different latitudes. 
In Figure 15, the heating load is shown and calculated as $3660.2 \mathrm{~kW} \cdot \mathrm{h}$ in Shanghai, $6714.7 \mathrm{~kW} \cdot \mathrm{h}$ in Seoul, $8140.6 \mathrm{~kW} \cdot \mathrm{h}$ in Sapporo, according to the different ambient temperatures of each location.

The simulation results are shown in Table 6. Because of the relatively large heating load and less storage energy, the soil temperature of Sapporo is lower than that of the other two cities. This is confirmed in Figure 16. Therefore, the system with the weather condition of Sapporo achieves the worst performance, where the heat exchange rate was $40.1 \mathrm{~W} / \mathrm{m}$. The heat pump COP is $4.56 \%$ and $7.7 \%$ lower than that of Shanghai. On the other hand, in the view of energy use ratio, the result of Sapporo was higher than that of the other cases. The energy use ratio means the ratio of the extracted heat to the stored solar heat. Figure 17 shows the average of stored solar heat and energy use ratio. Although the stored solar energy in Sapporo is $7000.2 \mathrm{~kW} \cdot \mathrm{h}$, which is $1109.8 \mathrm{~kW} \cdot \mathrm{h}$ less than that of Seoul, the energy use ratio of Sapporo was 55.4\%, 0.6\% higher than that of Seoul. This system in the location of low altitude is more efficient than it in the higher altitude due to higher ambient temperature and stronger solar radiation. However, in the view of the energy use ratio, the location of cold climate can more effectively utilize the effect of underground heat storage with solar heat. Therefore, it is necessary to develop suitable technology of underground heat storage for the climate such as the development of the grout material or the pipe type.

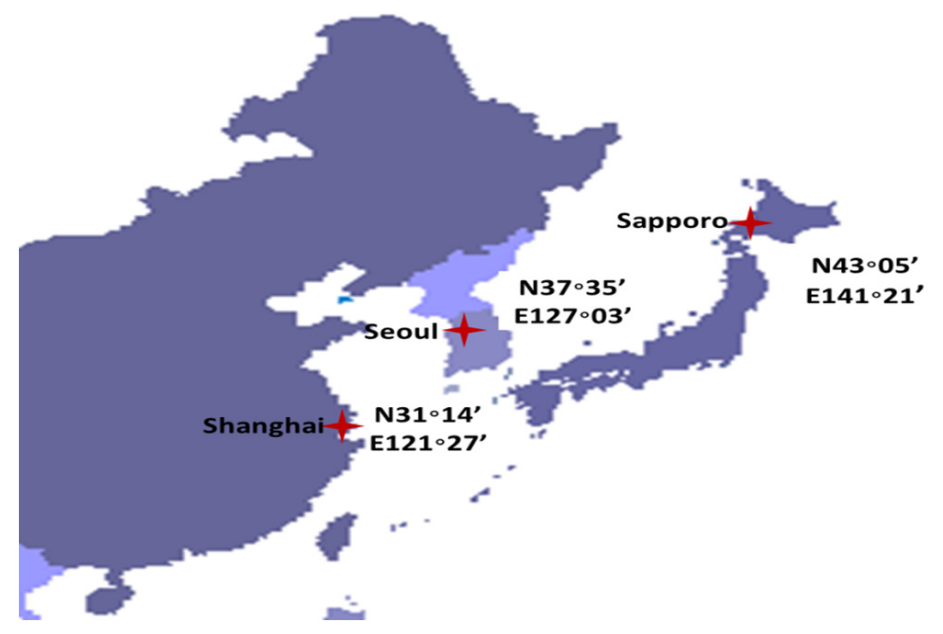

Figure 14. Location information of cities.

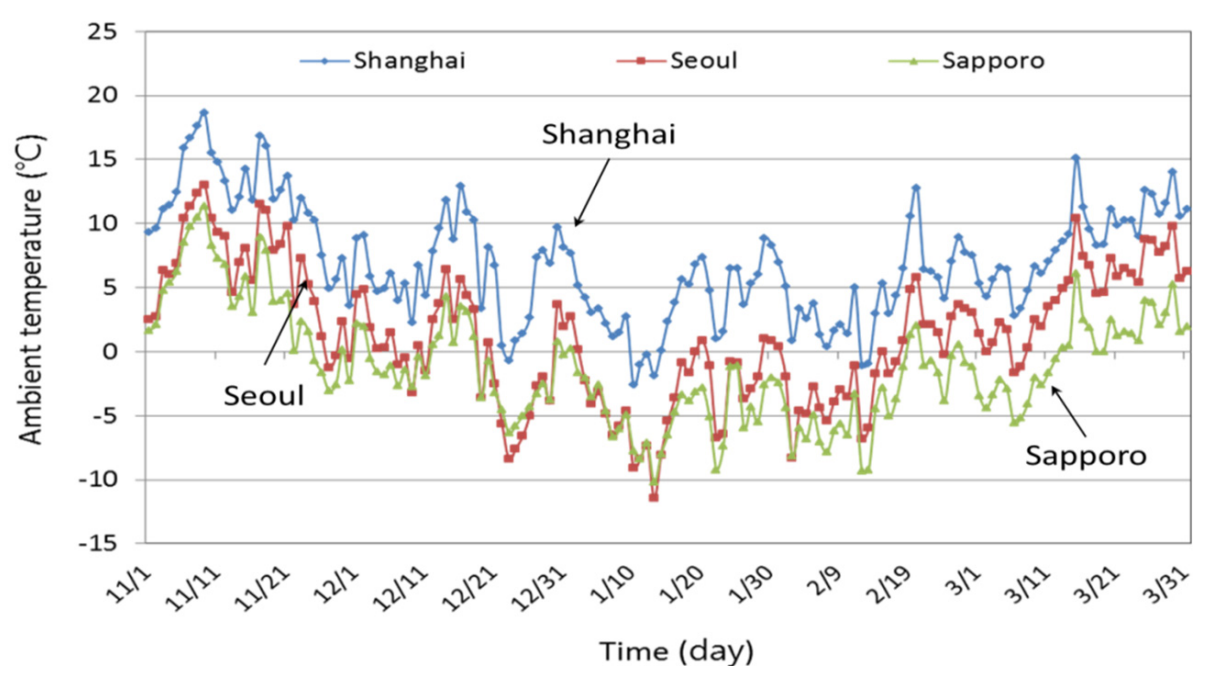

Figure 15. Ambient temperature of cities. 
Table 6. Simulation results with different weather conditions.

\begin{tabular}{cccccc}
\hline City & $\begin{array}{c}\text { Heat Exchange } \\
\text { Rate }(\mathbf{W} / \mathbf{m})\end{array}$ & $\begin{array}{c}\text { Heat Source } \\
\text { Temperature }\left({ }^{\circ} \mathbf{C}\right)\end{array}$ & $\begin{array}{c}\text { Heat Pump } \\
\text { COP }\end{array}$ & $\begin{array}{c}\text { Extraction } \\
\text { Energy } \mathbf{( k W} \cdot \mathbf{h})\end{array}$ & $\begin{array}{c}\text { Injection } \\
\text { Energy } \mathbf{( k W} \cdot \mathbf{h})\end{array}$ \\
\hline Shanghai & 48.6 & 9.5 & 4.94 & 7348.5 & 7313.5 \\
Seoul & 43.3 & 8.9 & 4.69 & 10062.9 & 8110.0 \\
Sapporo & 40.1 & 8.5 & 4.56 & 10966.1 & 7000.2 \\
\hline
\end{tabular}

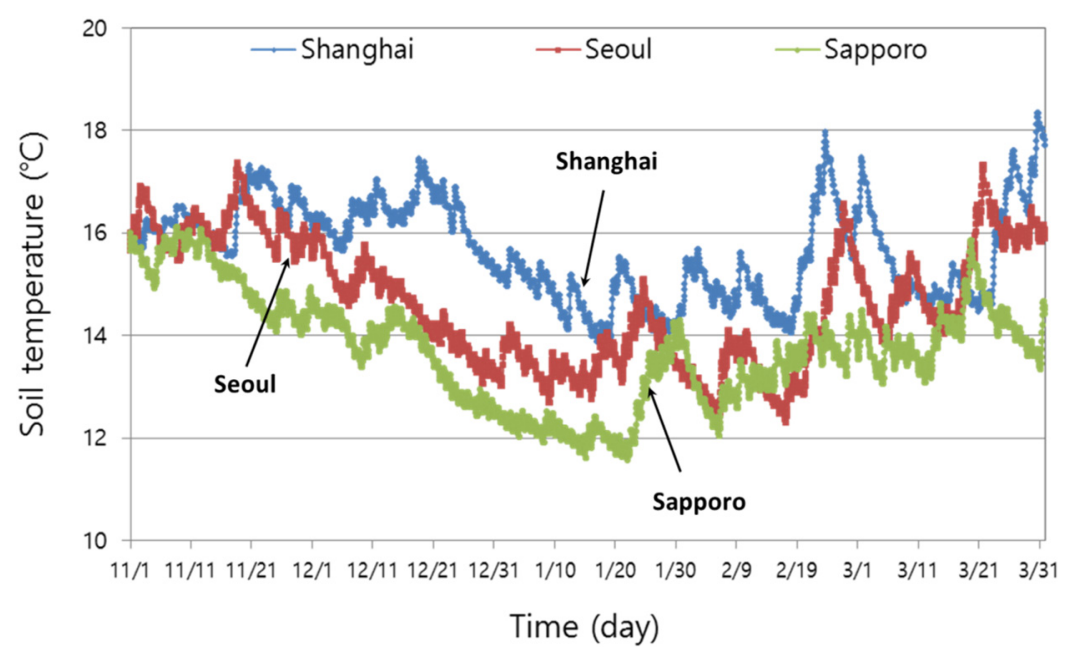

Figure 16. Soil temperature at different locations.

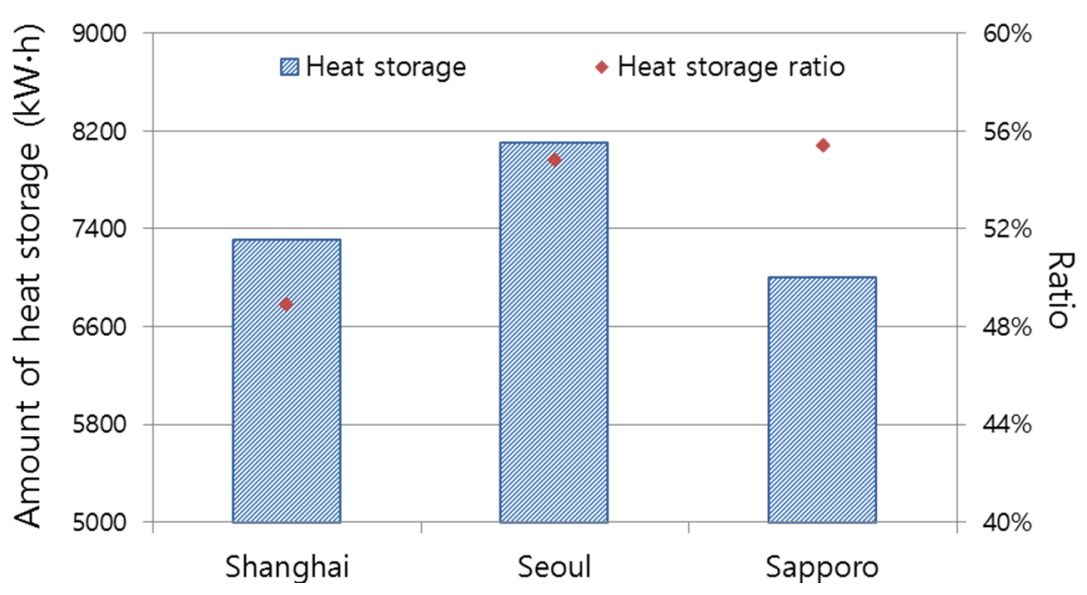

Figure 17. Simulation results of the stored solar heat and energy use ratio.

\section{Conclusions}

In this paper, a ground heat pump system integrated with solar thermal storage is suggested to solve the performance degradation problem caused by the drop in soil temperature. In addition, the performance of the system is analyzed and compared under difficult heating conditions using the simulation tool TRNSYS. Conclusions can be drawn as follows:

- The ground heat pump system assisted by solar thermal can effectively maintain the soil temperature balance. In addition, under the same operation conditions, the performance of SAGHPS is better than that of GSHPS. During the entire operation time, the heat exchange rate and heat pump COP of SAGHPS were $43.3 \mathrm{~W} / \mathrm{m}$ and 4.7. Compared with GSHPS, these values increased by $28.1 \%$ and $9.3 \%$, respectively. 
- With the increase of the collector area and the upgraded heating performance of the system, the investment costs increased relatively. From the result of the LCC assessment, when the solar collector area increased from $50 \mathrm{~m}^{2}$ to $90 \mathrm{~m}^{2}$, the payback period of SAGHPS would be in the range of 10 to 12 years.

- In contrast to other methods, using a high thermal conductivity grouting not only increases the heating performance of the heat pump, but also increases the energy use ratio.

- In different locations, because of the climatic differences, the performance of the system also differs. In a subtropical area (Shanghai), the system achieves a better heating performance than that in a cold area (Sapporo). However, in the cold area, the system achieved the best solar storage ratios, which were $55.4 \%, 0.6 \%$, and $6.5 \%$ higher than those of Seoul and Shanghai.

- In the next research stage, the simulation results will be verified through a demonstration experiment. Also, in order to establish the optimum design method of the suggested system, more case studies will be conducted.

The performance advantages of the suggested system were established through this study. However, it was also found that the effect of ground heat storage using solar heat was not directly connected to significant improvements of the system performance in all cases. This indicates that considering the additional installation cost of a solar collector, the SAGHPS cannot always achieve higher cost performance than GSHPS. In order to effectively utilize the system and verify the feasibility of the system, it is necessary not only to install at a location with high radiation and ground thermal conductivity, but also to introduce low cost solar heat collectors.

Acknowledgments: This work was supported by the New \& Renewable Energy Core Technology Program of the Korea Institute of Energy Evaluation and Planning (KETEP), granted financial resource from the Ministry of Trade, Industry \& Energy, Republic of Korea. (NO. 20133030110900).

Author Contributions: All authors contributed equally to this work. All authors designed the simulations, discussed the results and implications and commented on the manuscript at all stages. Yu Jin Nam and Xin Yang Gao performed the energy simulations and Yu Jin Nam led the development of the paper. Sung Hoon Yoon and Kwang Ho Lee performed the result analysis and discussion.

Conflicts of Interest: The authors declare no conflict of interest.

\section{Nomenclature}

$\begin{array}{ll}V_{\mathrm{DST}} & \text { The volume of the storage }\left(\mathrm{m}^{3}\right) \\ n & \text { Borehole number } \\ h & \text { The length of borehole }(\mathrm{m}) \\ B & \text { Borehole spacing }(\mathrm{m}) \\ T_{\mathrm{r}} & \text { Indoor temperature }\left({ }^{\circ} \mathrm{C}\right) \\ T_{\mathrm{st}} & \text { Average temperature of storage tank }\left({ }^{\circ} \mathrm{C}\right) \\ T_{\mathrm{s}} & \text { Solar source temperature }\left({ }^{\circ} \mathrm{C}\right) \\ T_{\mathrm{g}} & \text { Ground source temperature }\left({ }^{\circ} \mathrm{C}\right) \\ \mathrm{COP} & \text { The heat pump coefficient of performance } \\ \mathrm{Cap} & \text { Heat pump heating capacity }(\mathrm{kW}) \\ P & \text { Power consumption of the system }(\mathrm{kW}) \\ P_{\mathrm{HP}} & \text { Power consumption of the heat pump }(\mathrm{kW}) \\ Q & \text { Energy production of system }(\mathrm{kW}) \\ Q_{\text {heat }} & \text { Heat transfer rate }(\mathrm{kW}) \\ Q_{\mathrm{absorbed}} & \text { Energy absorbed by the heat pump }(\mathrm{kW}) \\ Q_{\text {injection }} & \text { Solar storage energy }(\mathrm{kW}) \\ Q_{\text {solar }} & \text { Energy absorbed by solar collector }(\mathrm{kW}) \\ T_{\text {source, in }} & \text { Temperature of liquid entering the source side of the heat pump }\left({ }^{\circ} \mathrm{C}\right) \\ T_{\text {source, out }} & \text { Temperature of liquid exiting the source side of the heat pump }\left({ }^{\circ} \mathrm{C}\right) \\ T_{\text {load, in }} & \text { Temperature of liquid entering the load side of the heat pump }\left({ }^{\circ} \mathrm{C}\right) \\ T_{\text {load, out }} & \text { Temperature of liquid exiting the load side of the heat pump }\left({ }^{\circ} \mathrm{C}\right) \\ T_{\text {fluid, in }} & \text { Inlet fluid temperature of the borehole }\left({ }^{\circ} \mathrm{C}\right) \\ T_{\text {fluid, out }} & \text { Outlet fluid temperature of the borehole }\left({ }^{\circ} \mathrm{C}\right)\end{array}$




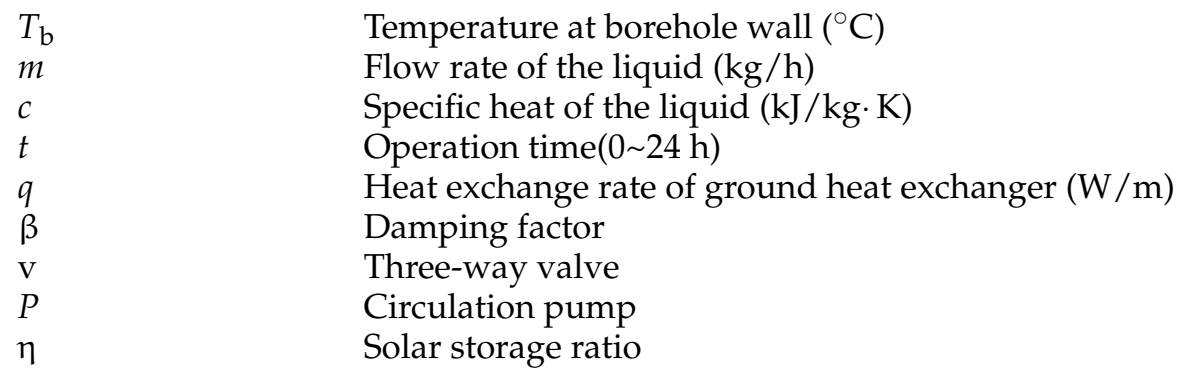

\section{References}

1. Dincer, I. Renewable energy and sustainable development: A crucial review. Renew. Sustain. Energy Rev. 2000, 4, 157-175. [CrossRef]

2. International Geothermal Association Home Page. Available online: http://www.geothermal-energy.org/ (accessed on 10 September 2015).

3. Ozgener, O.; Hepbasli, A. A review on the energy and exergy analysis of solar assisted heat pump systems. Renew. Sustain. Energy Rev. 2007, 11, 482-496. [CrossRef]

4. Bose, J.E.; Ledbetter, C.W.; Partin, J.R. Experimental results of a low cost solar-assisted heat pump system using earth coil and geo-thermal well storage. Available online: http://www.osti.gov/ scitech/servlets/purl/6890048 (accessed on 10 September 2015).

5. Ozgener, O.; Hepbasli, A. Experimental performance analysis of a solar assisted ground-source heat pump greenhouse heating system. Energy Build. 2005, 37, 101-110. [CrossRef]

6. Bakirci, K.; Ozyurt, O.; Comakli, K.; Comakli, O. Energy analysis of a solar-ground source heat pump system with vertical closed-loop for heating applications. Energy 2011, 36, 3224-3232. [CrossRef]

7. Trillat-Berdal, V.; Souyri, B.; Fraisse, G. Experimental study of a ground-coupled heat pump combined with thermal solar collectors. Energy Build. 2006, 38, 1477-1484. [CrossRef]

8. Trillat-Berdal, V.; Souyri, B.; Achard, G. Coupling of geothermal heat pumps with thermal solar collectors. Appl. Ther. Eng. 2007, 27, 1750-1755. [CrossRef]

9. Yang, W.B.; Shi, M.H.; Dong, H. Numerical simulation of the performance of a solar-earth source heat pump system. Appl. Ther. Eng. 2006, 26, 2367-2376. [CrossRef]

10. Nam, Y.J. Study on the optimum design of a heat pump system using solar and ground heat. J. SAREK 2012, 24, 509-514. [CrossRef]

11. Han, Z.; Zheng, M.; Kong, F.; Wang, F.; Li, Z.; Bai, T. Numerical simulation of solar assisted ground-source heat pump heating system with latent heat energy storage in severely cold area. Appl. Ther. Eng. 2008, 28, 1427-1436. [CrossRef]

12. Lazzarin, R. Dual source heat pump systems: Operation and performance. Energy Build. 2012, 52, 77-85. [CrossRef]

13. Busato, F.; Lazzarin, R.; Noro, M. Two years of recorded data for a multisource heat pump system: A performance analysis. Appl. Ther. Eng. 2013, 57, 39-47. [CrossRef]

14. Busato, F.; Lazzarin, R.; Noro, M. Multisource heat pump system from design to operation: The case study of a new school building. Int. J. Low Carbon Technol. 2013, 8, 88-94. [CrossRef]

15. Busato, F.; Lazzarin, R.; Noro, M. Ground or solar source heat pump systems for space heating: Which is better? Energetic assessment based on a case history. Energy Build. 2015, 102, 347-356. [CrossRef]

16. D’Antoni, M.; Sparber, W. IEA-SHC Task 44/Annex 38 Solar and Heat Pump Systems. 2013. Available online: http://task44.iea-shc.org/ (accessed on 30 September 2015).

17. Kim Young-Tag, A. Study on the Development of the Representing Day Heating Load Model for the Estimation of Energy Consumption in an Apartment House. J. Arch. Inst. Korea Plan. Des. 2005, 21, 287-294.

18. Bernier, M.; Randriamiarinjatove, D. Annual simulations of heat pump systems with vertical ground heat exchangers. In Proceedings of the Conference on Building Energy Simulation, Ottawa, ON, Canada, 2001; pp. 163-170.

19. Hellström, G. Duct Ground Heat Storage Model, Manual for Computer Code; Department of Mathematical Physics, University of Lund: Lund, Sweden, 1989. 
20. Pahud, D.; Hellström, G.; Mazzarella, L. Duct Ground Heat Storage Model for TRNSYS (TRNVDST); Laboratory of Energy Systems: Lausanne, Switzerland, 1997.

21. Nam, Y.J.; Ooka, R.; Hwang, S. Development of a numerical model to predict heat exchange rates for a ground-source heat pump system. Energy Build. 2008, 40, 2133-2140. [CrossRef]

22. Nam, Y.J.; Oh, J.H. Study on the characteristic of heat exchange for vertical geothermal system using the numerical simulation. J. Korean Solar Energy Soc. 2014, 34, 66-72. [CrossRef]

23. Web Site of Korean Ministry of Trade, Industry and Energy. Available online: http://motie.go.kr/motie/ne/presse/press2/bbs/bbsView.do?bbs_seq_n=59155\&bbs_cd_n=81 (accessed on 30 September 2015).

(C) 2015 by the authors; licensee MDPI, Basel, Switzerland. This article is an open access article distributed under the terms and conditions of the Creative Commons by Attribution (CC-BY) license (http://creativecommons.org/licenses/by/4.0/). 